\title{
Association of Melanocortin 4 Receptor gene polymorphism with growth traits in Bligon goat
}

\author{
L. Latifah ${ }^{1}$, D. Maharani ${ }^{1}$, A. Kustantinah ${ }^{2}$ and T. Hartatik ${ }^{1, *}$ \\ ${ }^{1}$ Department of Animal Breeding and Reproduction, Faculty of Animal Science, \\ Universitas Gadjah Mada, Jl. Fauna No. 3, Sleman-Yogyakarta - Indonesia \\ ${ }^{2}$ Department of Animal Nutrition and Feed Science, Faculty of Animal Science, \\ Universitas Gadjah Mada, Jl. Fauna No. 3, Sleman-Yogyakarta - Indonesia \\ *CorrespondingE-mail: tety@ugm.ac.id
}

Received June 26, 2018; Accepted August 30, 2018

\begin{abstract}
ABSTRAK
Gen Melanocortin 4 Receptor merupakan marker gen yang potensial untuk pertumbuhan pada hewan ruminansia dan non-ruminansia. Tujuan penelitian ini untuk mengidentifikasi frekuensi alel dan genotip, dan hubungan gen MC4R dengan sifat pertumbuhan pada kambing Bligon. Total 77 sampel darah telah dikoleksi dan diisolasi DNA. Sepasang primer digunakan untuk amplifikasi gen MC4R (F: 5'-TCGGGCGTCTTGTTCATCAT-3' dan R: 5'-CAAGACTGGGCACTGCTTCA-3') menggunakan metode PCR. Dua SNP g.998A/G dan g.1079C/T terletak di exon teridentifikasi dengan menggunakan metode sekuensing DNA dan PCR-RFLP. Pada SNP g.998A/G teridentifikasi adanya perubahan asam amino isoleusin ke metionin (I-M), sedangkan SNP g.1079C/T bersifat synonymous polymorphism. Berdasarkan analisis hubungan antara genotip gen MC4R (SNP g.998A/G) dan sifat pertumbuhan pada genotip GG paling rendah untuk bobot sapih (BS; $\mathrm{AA}=13.0 \pm 1.7 ; \mathrm{AG}=11.2 \pm 3.6 ; \mathrm{GG}=9.2 \pm 3.9$ ), panjang badan sapih (PBS; $\mathrm{AA}=46.8 \pm 2.4 ; \mathrm{AG}=46.3 \pm 6.0 ; \mathrm{GG}=43.8 \pm 5.3$ ) dan lingkar dada sapih (LDS; $\mathrm{AA}=50.9 \pm 4.0 ; \mathrm{AG}=50.7 \pm 4.6 ; \mathrm{GG}=47.1 \pm 7.3)$ jika dibandingkan dengan genotip $\mathrm{AA}$ dan $\mathrm{AG}(\mathrm{P}<0.05)$. Individu dengan genotip $\mathrm{CC}$ dan $\mathrm{CT}$ pada SNP g.1079C/T $(\mathrm{P}<0.05)$ untuk $\mathrm{BS}(\mathrm{CC}=10,6 \pm 2.1$; $\mathrm{CT}=12.5 \pm 2.5)$ dan pertambahan bobot badan harian $(\mathrm{PBBH} ; \mathrm{CC}=81.2 \pm 21.8 ; \mathrm{CT}=79.3 \pm 26.2)$ dari pada TT $(\mathrm{BS}=10.6 \pm 3.1$; $\mathrm{PBBH}=58.3 \pm 30.5$ ). Hasil penelitian ini mengindikasi bahwa SNP g.998A/G dan g.1079C/T dapat dijadikan marker genetik sifat pertumbuhan untuk seleksi kambing Bligon.
\end{abstract}

Kata Kunci: Bligon, kambing, MC4R, SNP, sifat pertumbuhan, asosiasi

\begin{abstract}
Melanocortin 4 receptor gene is a potential marker gene for growth performance in ruminant and non-ruminant animals. The objective of this study was to perform allele and genotype frequencies, and association of melanocortin 4 receptor with growth traits in Bligon goat. Seventy seven blood samples were collected and DNA isolated successfully. One pair primers were used for PCR of MC4R gene (F: 5'-TCGGGCGTCTTGTTCATCAT-3' and R: 5'-CAAGACTGGGCACTGCTTCA-3'). Two SNPs (g.998A/G and g.1079C/T) were identified in exon of Bligon MC4R by DNA sequencing and PCRRFLP. The SNP g.998A/G identified amino acid change from isoleucine to methionine (I-M), while the SNP g.1079C/T was synonymous polymorphism. Based on relationship analysis between Genotype of MC4R gene (SNP g.998A/G) and growth traits indicated that GG genotype was lowest in weaning weight (WW; $\mathrm{AA}=13.0 \pm 1.7 ; \mathrm{AG}=11.2 \pm 3.6 ; \mathrm{GG}=9.2 \pm 3.9$ ), weaning body length (WBL; $\mathrm{AA}=46.8 \pm 2.4$;
\end{abstract}


$\mathrm{AG}=46.3 \pm 6.0 ; \mathrm{GG}=43.8 \pm 5.3$ ) and weaning chest circumference (WCC; $\mathrm{AA}=50.9 \pm 4.0 ; \mathrm{AG}=50.7 \pm 4.6$; $\mathrm{GG}=47.1 \pm 7.3)$ compare to $\mathrm{AA}$ and $\mathrm{AG}$ genotype $(\mathrm{p}<0.05)$. Individual with $\mathrm{CC}$ and $\mathrm{CT}$ genotypes at $\mathrm{SNP}$ g.1079C/T had higher $(\mathrm{P}<0.05)$ in $\mathrm{WW}(\mathrm{CC}=12.6 \pm 2.1 ; \mathrm{CT}=12.5 \pm 2.5)$ and average daily gain (ADG; $\mathrm{CC}=81.2 \pm 21.8 ; \mathrm{CT}=79.3 \pm 26.2$ ) than $\mathrm{TT}$ genotype (WW=10.6 $\pm 3.1 ; \mathrm{ADG}=58.3 \pm 30.5$ ). This results suggested that SNP g.998A/G and g.1079C/T of MC4R gene could be used as the genetic marker of growth traits for selection in Bligon goat.

Keywords: Bligon, goat, MC4R, SNP, growth traits, association

\section{INTRODUCTION}

Indonesia has many goats (Bligon, Kacang, Kecobong, Samosir, Kosta, Benggala, Muara and Peranakan Etawah) that live in both intensive and extensive rearing system. Grass and roughage are the main diets for goats in two rearing systems. The domestic goat is categorized as Capra, Caprovinae, and ruminant. Bligon goat is a crossbreed between Kacang and Peranakan Etawah goat (Budisatria et al., 2009; Suhartanto and Kustantinah, 2009; Hartatik, 2014). The growth of Bligon is influenced by genetic and environment (Hardjosubroto, 1994). The recent study, molecular genetics has provided a new system for selection goats based on genetics marker that significantly influenced growth traits. Growth traits are affected by many pairs of genes. The melanocortin 4 receptor gene is among the candidate genes for growth traits in goats (Jun et al., 2013).

Melanocortin 4 receptor (MC4R) gene, which leds to pharmacological tool development, is a model of melanocortin system in controlling the energy balance. The MC4R gene function to regulate food intake and homeostasis. This role has been shown to be evolutionarily conserved in vertebrates (Andersone et al., 2016). Allele and genotype distribution of MC4R gene have been described by many researchers in monogastric and polygastric animal such as in chicken (Yan et al., 2013), pig (Piorkoswka et al., 2010; Davoli et al., 2012; Zhang et al., 2017), sheep (Song et al., 2014; Wang et al., 2015), cattle (Huang et al., 2010; Liu et al., 2010; Maharani et al., 2018) and buffalo (Deng et al., 2016).

The genotype of MC4R gene based on single nucleotide polymorphism has also been reported as genetic marker for body weight in female Beagle dogs (Zheng et al., 2014), sexual desire behavior, feed intake and finishing weight in rabbit (Fontanesi et al., 2013; El-Sabrout, 2017; El-Sabrout and Soliman, 2017), egg production in Langsan chicken (Yan et al., 2013), feed intake, body weight and ADG in yak (Cai et al., 2015), back fat thickness and marbling score in Korean cattle (Seong et al., 2012), birth body length in Kebumen cattle (Maharani et al., 2018), ADG, loin-eye area and meat quality in sheep (Zou et $a l ., 2014$ ) and milk production in buffalo (Deng et al., 2016). In the previous study, genetics analysis (SNPs detection, amino acid change, restriction enzyme mapping and phylogenetic tree) of MC4R gene were reported in Bligon goat (Latifah et al., 2017). However, no reports yet on the allele and genotype frequency, and association of MC4R gene with the growth traits study have been identified in Bligon goat. The work of MC4R gene in monogastric and polygastric animals suggested that it may be an important genetic marker in Bligon goat. Therefore, the objective of this study was to perform allele and genotype frequency, and association study of MC4R gene with growth traits in the Bligon goat.

\section{MATERIALS AND METHODS}

\section{Animal and DNA Samples}

Seventy seven blood samples (female $=43$ heads; male $=34$ heads) were collected from Bligon goat. The samples were randomly selected from a local farmer in Banyusoco village, Gunungkidul, Special Region of Yogyakarta, Indonesia. The body weight, body measurement (BL: body length; CC: chest circumference; HS: height of shoulder; $\mathrm{HH}$ : height of hip) and average daily gain (ADG; from the birth to the 3rd month) were observed. The blood samples were collected and maintained in an ice box being transport to the laboratory. Genomic DNA of each genomic DNA was extracted from the blood using $S Y N C^{T M}$ DNA Extraction Kit (Geneaid, Taiwan) method.

\section{MC4R Gene Genotyping}

PCR was performed using the primers MC4R F (F: 5'-TCGGGCGTCTTGTTCATCAT3') and primer $\mathrm{R}$ (R: 5'- 
CAAGACTGGGCACTGCTTCA-3'), designed by Latifah et al. (2017) to PCR a fragment of 642 $\mathrm{bp}$ in length covering the exon and 3'UTR of the goat MC4R gene. PCR was performed in the 30 $\mu 1$ reaction mixture containing $10 \mu \mathrm{l}$ of double distilled water (DDW), $1.5 \mu 1$ of primer F and R, $15 \mu \mathrm{l}$ of PCR kit (KAPPABIOSYSTEMS, USA), and $2 \mu \mathrm{l}$ of DNA genome. The protocol was followed: the pre-denaturation temperature at $94^{\circ} \mathrm{C}$ for $3 \mathrm{~min}, 35$ cycles of denaturation at $94^{\circ} \mathrm{C}$ for $30 \mathrm{sec}$, annealing at $57.8^{\circ} \mathrm{C}$ for $30 \mathrm{sec}$, extension at $72^{\circ} \mathrm{C}$ for $30 \mathrm{sec}$, and followed by a final extension at $72^{\circ} \mathrm{C}$ for $10 \mathrm{~min}$. The product PCR was sequenced with the same primer. Sequencing was performed by 1 st Base DNA sequencing, Malaysia. The MC4R gene sequence of 21 Bligon goats was aligned and edited in Bioedit ver. 7.00. Polymorphism sites of nucleotide and amino acid sequence of the coding region of MC4R gene were analyzed using Bioedit ver. 7.00. The method of detection SNPs and amino acid change were described by Hartatik (2016). The SNP g.1079C/T from 56 samples was used for genotyping using PCRrestriction fragment length polymorphism (PCRRFLP) method. The restriction enzyme digestion was performed in $9 \mu 1$ reaction volumes with approximately $4 \mu \mathrm{l}$ of PCR products, $3.3 \mu \mathrm{LDW}$, $1.5 \mu 1$ buffer 1.1 , and $0.2 \mu 1$ of Kpn 1 restriction enzyme ( 3 hours incubation at $37^{\circ} \mathrm{C}$ ). The digested products were run on $3 \%$ agarose gel.

\section{Data Analysis}

The growth traits of Bligon were adjusted based on birth type, age of doe and gender. The adjusted data analysis using the method that described by Hardjosubroto (1994). The following models were:

\section{Adjusted BW $=$ Actual BW x BTF x ADF x SF}

Adjusted WW $=\left(\right.$ Actual BW $\left.+\frac{\text { Actual WW }- \text { Actual BW }}{\text { Age }} \times 100\right) \times$ BTF x ADF x GF

Where: BW is birth weight, WW is weaning weight, BTF is birth type factor, ADF is an age of doe factor and GF is sex factor. The genotype of Bligon goats were determined by sequencing and PCR-RFLP analysis. Test of Person's Chi-square was used to verify the samples not deviant to Hardy-Weinberg equilibrium. The model analysis was:

$$
X^{2}=\sum_{i=1}^{n} \frac{\left(O_{i}-E_{i}\right)^{2}}{E_{i}}
$$

Where: $\mathrm{X}^{2}$ is chi-square value, $\mathrm{O}_{\mathrm{i}}$ is observed frequency, $E_{i}$ is expected frequency and $n$ is Number of data. The association between growth traits and genotype of MC4R SNP were analyzed using one way ANOVA procedure in the software SPSS ver. 16.00 (SPSS, USA). The model was as follows:

$$
\text { Yij }=\mu+a i+\epsilon i j
$$

Where $\mathrm{Y}$ is the phenotypic data (body weight, body measurement, and average daily gain) of the sample, $\mu$ is the overall mean, $\alpha$ is the genotype effect of sample $\mathrm{i}$ and $\varepsilon$ is a random error. Duncan's test was performed to analyze the pairwise differences between the genotypes.

\section{RESULTS AND DISCUSSION}

\section{SNPs Detection, Allele and Genotype Frequencies}

The 642 bp product PCR of Bligon MC4R gene was sequenced, including 461 of exon 1 and 181 of 3'UTR (the location of PCR target at 9241562 based on Genbank Acc. No

Table 1. Allele, Genotype Frequencies and Hardy-Weinberg Equilibrium in MC4R Gene of Bligon

\begin{tabular}{ccrccc}
\hline SNP & Genotype & N & Genotype Frequency & Allele Frequency & $X^{2}$ \\
\hline g.998A/G & AA & 10 & 0.47 & $\mathrm{~A}=0.67$ & 0.30 \\
& AG & 8 & 0.38 & $\mathrm{G}=0.33$ & \\
g. $1079 \mathrm{C} / \mathrm{T}$ & GG & 3 & 0.15 & & \\
& CC & 46 & 0.60 & $\mathrm{C}=0.74$ & 5.07 \\
& CT & 22 & 0.12 & $\mathrm{~T}=0.26$ & \\
& TT & 9 & 0.28 & & \\
\hline
\end{tabular}

$\mathrm{N}=$ number of data

$\mathrm{X}^{2}$ in the table of Person's Chi-square test 0.05;2 $=5.99$ 
NM_001285591). This study was the first to evaluate the relationship of SNPs in the MC4R gene on growth traits in Bligon. In our study, two SNPs were identified in Bligon MC4R gene (Table 1). The SNPs in MC4R gene was initially identified by direct sequencing using 21 samples of PCR product. The SNP was confirmed by Bioedit program. As the results, two SNPs of MC4R gene were identified in exon region: SNP g.998A/G and g.1079C/T (Figure 1A, B). The SNP g.998A/G was found to have amino acid variants I-M (isoleucine to methionine) as presented in Figure 2. However, no amino acid change has been detected in SNP g.1079C/T.

Three patterns (AA, AG and GG) were clearly detected at SNP g.998A/G, while three genotypes (CC, CT, and TT) were observed at location of SNP g.1079C/T. The SNP g.1079C/T was used for genotyping using PCR-RFLP (Kpn1 enzyme with restriction site G_GTAC'C) for 56 samples of Bligon. Homozygote $\mathrm{CC}$ genotype were defined when the fragments size was $642 \mathrm{bp}$, and TT genotype were recognized by 165 and 477 bp length of fragments. Heterozygous CT genotype produces fragments of 165, 477 and 642 bp (Figure 3).

Based on alignment result in the previous study and 2 Genbank (Acc. No. NM_001285591 and $\mathrm{JN}$ 107563.1), there were 2 SNP at SNP g. $998 \mathrm{~A} / \mathrm{G}$ and g.1079C/T in the coding region, and the SNP g.1515A/G was located at 3'UTR. The SNP g.998A/G changed amino acid from isoleucine to methionine (Latifah et al., 2017). The SNP g.1515A/G was not found in the Bligon population. Also, the SNP g.1515A/G was not identified in the Boer population (Jun et al., 2013). The SNP g.998A/G and g.1079C/T were not detected in the result of alignment with other goats (Genbank Acc. No. NM 001285591 and JN 107563.1) but both SNP g.998A/G and g.1079C/T was identified within the Bligon population (in this study). Both SNPs were detected in the alignment study of goat, sheep, cattle, and buffalo (Genbank Acc. No. NC_030831.1 Capra hircus; NC_037351.1 Bos taurus; NC_032673.1 Bos indicus; NC_019480.2 Ovis aries; NC_037566.1 Bubalus bubalis).

Allele and genotype frequencies, and HardyWeinberg equilibrium for two SNP were shown in Table 1. The A allele at SNP g.998A/G was dominant allele and the highest genotipype was AA (0.47). While at SNP g.1079C/T, the C Allele was the main allele. The highest number of $\mathrm{CC}$ (0.60) homozygote genotype was observed at SNP
g.1079C/T. Both SNP g.998A/G and g.1079C/T were in HWE because of estimation of the $x^{2}$ value lower than the $x^{2}$ value $(0.05 ; 2)$ in the table of Person's Chi-square test. Similar results have been reported in Yak population that five SNPs indicated no significant deviation from HWE (p>0.05) (Cai et al., 2013). The results of Pearson's Chi-square test in Kebumen cattle was not deviated from the HWE $(\mathrm{P}>0.05)$ (Maharani et al., 2018). In the Buffalo was identified eight SNPs at exon and 3'UTR region. Allele and genotype frequencies of six polymorphisms were appropriated in HWE ( $>0.05$ ), while two SNPs (g.226C/T and g.1525A/G) were not in HWE (Deng et al., 2015). The result of chi-square test showed that the chicken and pig species were not in HWE (Yan et al., 2013; Davoli et al., 2012).

\section{Association of MC4R Gene Polymorphism with Growth Traits}

The result of association analysis between the MC4R gene based on SNP g.998A/G and SNP g.1079C/T and growth traits shows in Table 2 and Table 3. A significant interaction between growth traits at birth and MC4R gene genotype released that SNP g.998A/G and SNP g.1079C/T was not found in all observed traits $(\mathrm{p}>0.05)$. However, the SNP g.998A/G was affected with weaning weight (WW), weaning body length (WBL) and weaning chest circumference (WCC). While the SNP g.1079C/T was significant association with WW and average daily gain (ADG). The AA and AG genotype had higher WW, WBL than that of GG genotype in the SNP g.998A/G $(\mathrm{P}<0.05)$. Similarly, in SNP g.1079C/T, the CC and CT significantly differed from TT in varied WW and ADG $(\mathrm{P}<0.05)$. These results indicated that the Bligon with $\mathrm{AA}$ and $\mathrm{AG}$ genotype at SNP g.998A/G had a tendency to gain more WW, WBL and WCC. Whereas CC and CT genotype at SNP g. $1079 \mathrm{C} / \mathrm{T}$ had a way to grow more WW and ADG. Our result indicated that polymorphisms (g.998A/G and g.1079C/T) could be used for a genetic marker in Bligon.

The SNP g.1079C/T was deep explored in this study although the SNP g.1079C/T only changed the codon GGC to GGT (synonymous polymorphism; proline). This is because the SNP g. $1079 \mathrm{C} / \mathrm{T}$ was recognized by the restriction enzyme Kpn 1 (G_GTAC'C). Many researches detected synonymous polymorphism that has been affected with growth traits in mammals (Seong et al., 2011; Zou et al., 2014). Hanwoo cattle with CT genotype displayed a significantly higher 


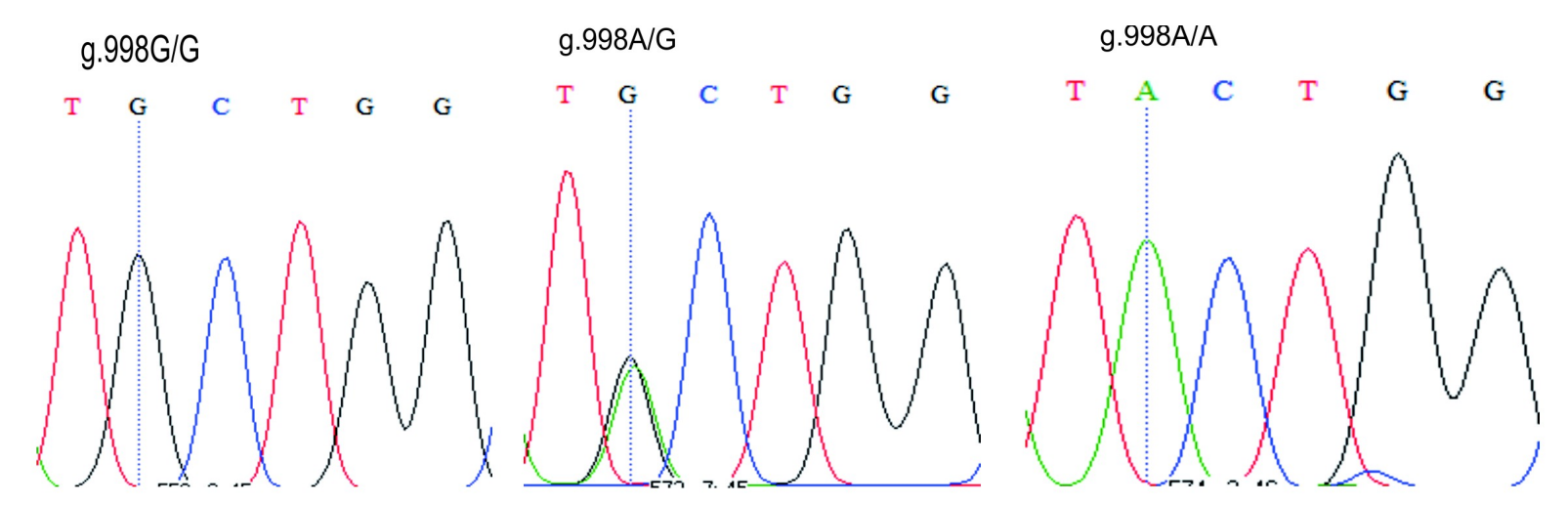

g.1079T/T

g.1079C/T

g. $1079 \mathrm{C} / \mathrm{C}$

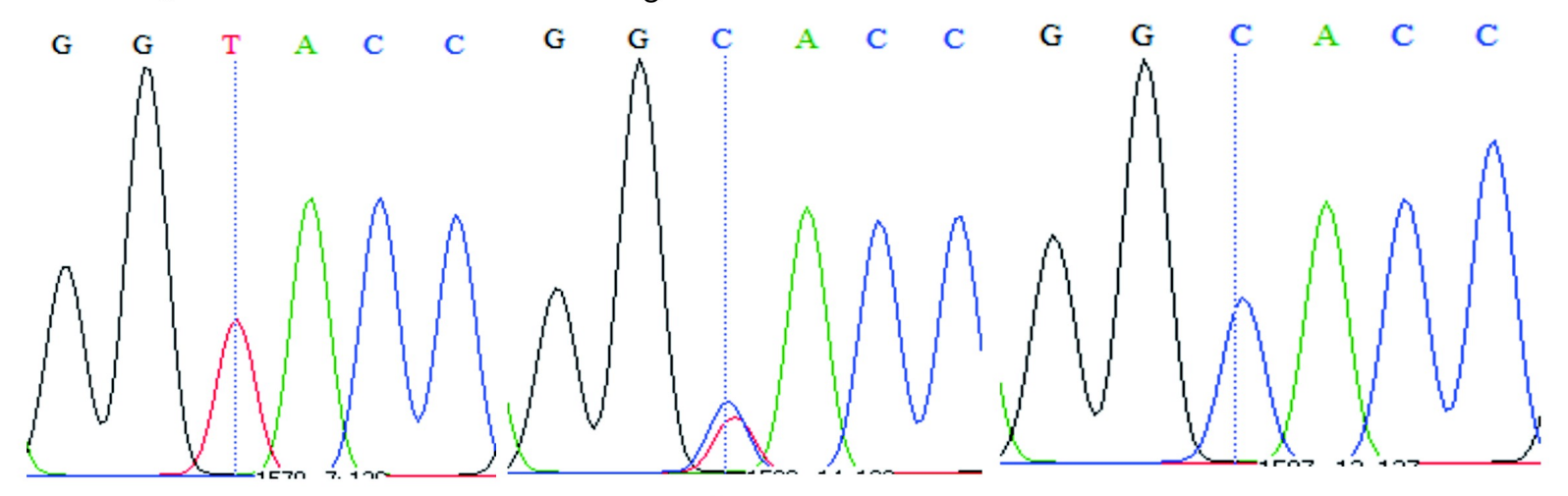

A

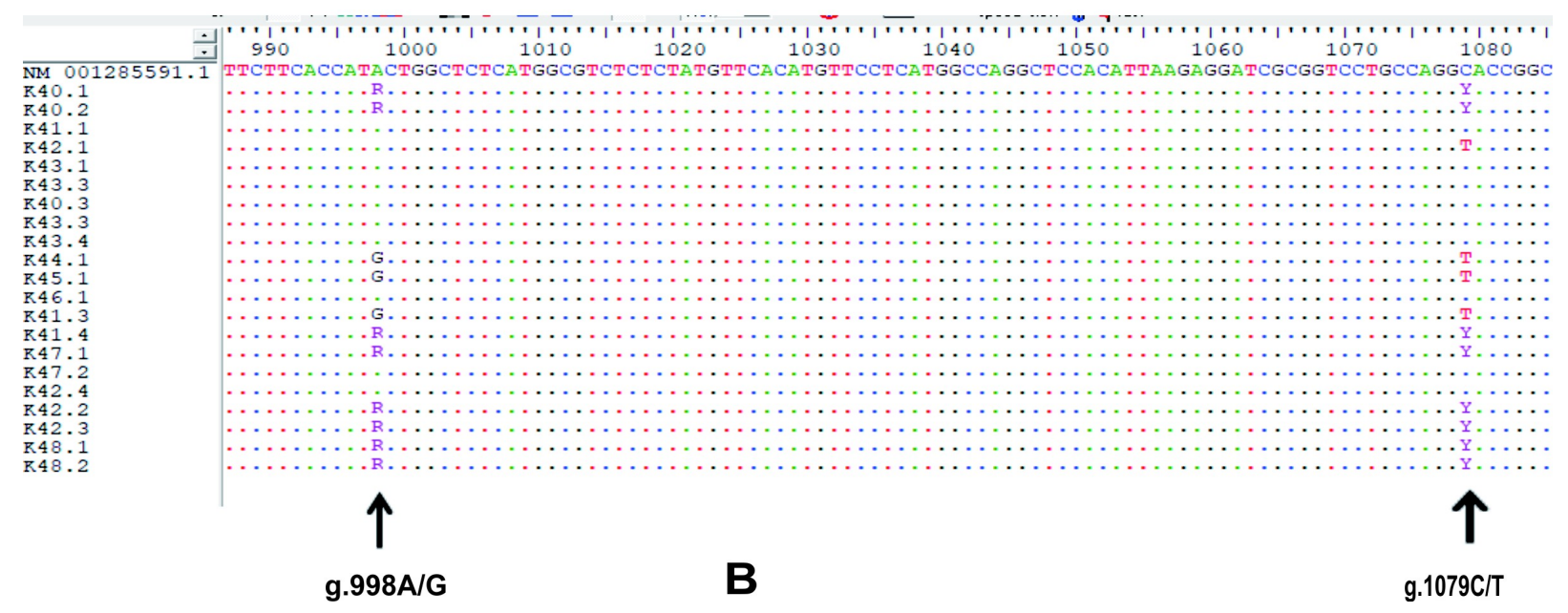

Figure 1(A, B). Detection of Two SNPs Based on MC4R Gene in Bligon (A) Electrophoregram and (B) Alignment sequence of $\mathrm{PCR}$ products; $\mathrm{R}$ is heterozygous $\mathrm{AG}$; $\mathrm{Y}$ is heterozygous $\mathrm{CT}$

marbling score than genotype $\mathrm{CC}$ and $\mathrm{TT}$ $(\mathrm{p}<0,05)$ based on SNP g.927C/T (GGC to GGT; glysine). Whereas the SNP g.1343C/A (ATC to ATA; lysine), there was a significant effect on the back fat. Hanwoo with CA genotype had higher back fat than that of CC and TT genotype (Seong et al., 2011). Water buffaloes with CT genotype at SNP g.1104C/T (AAC to AAT; lysine) had higher 


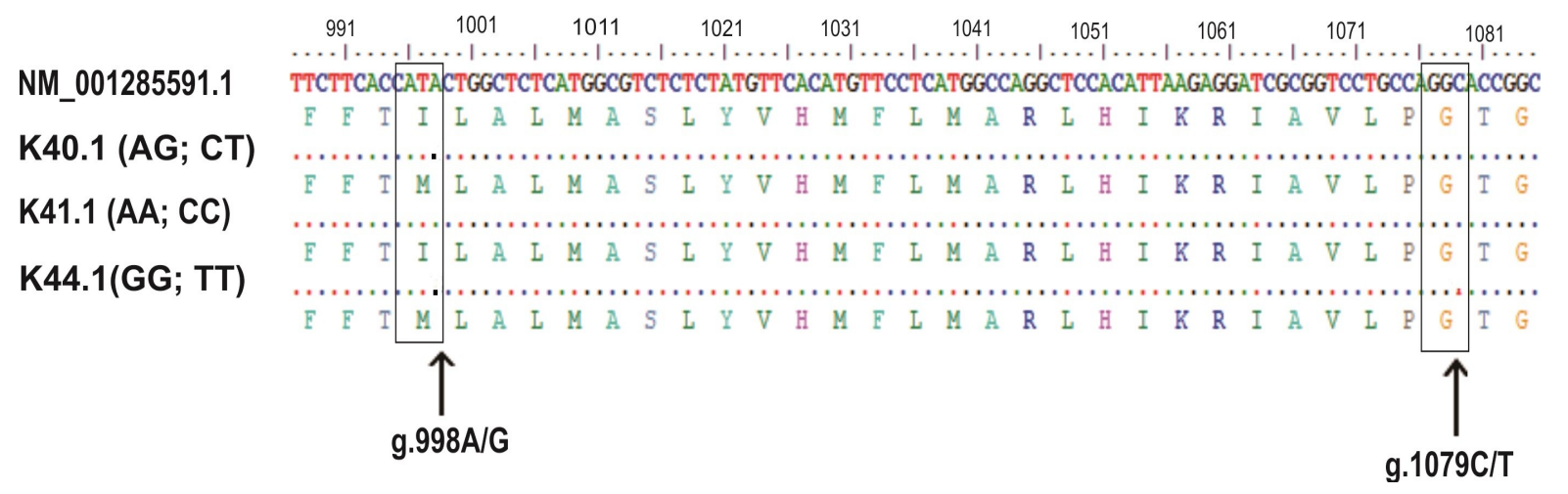

Figure 2. The Amino Acid Variant in Both SNP g.998A/G and g.1079C/T

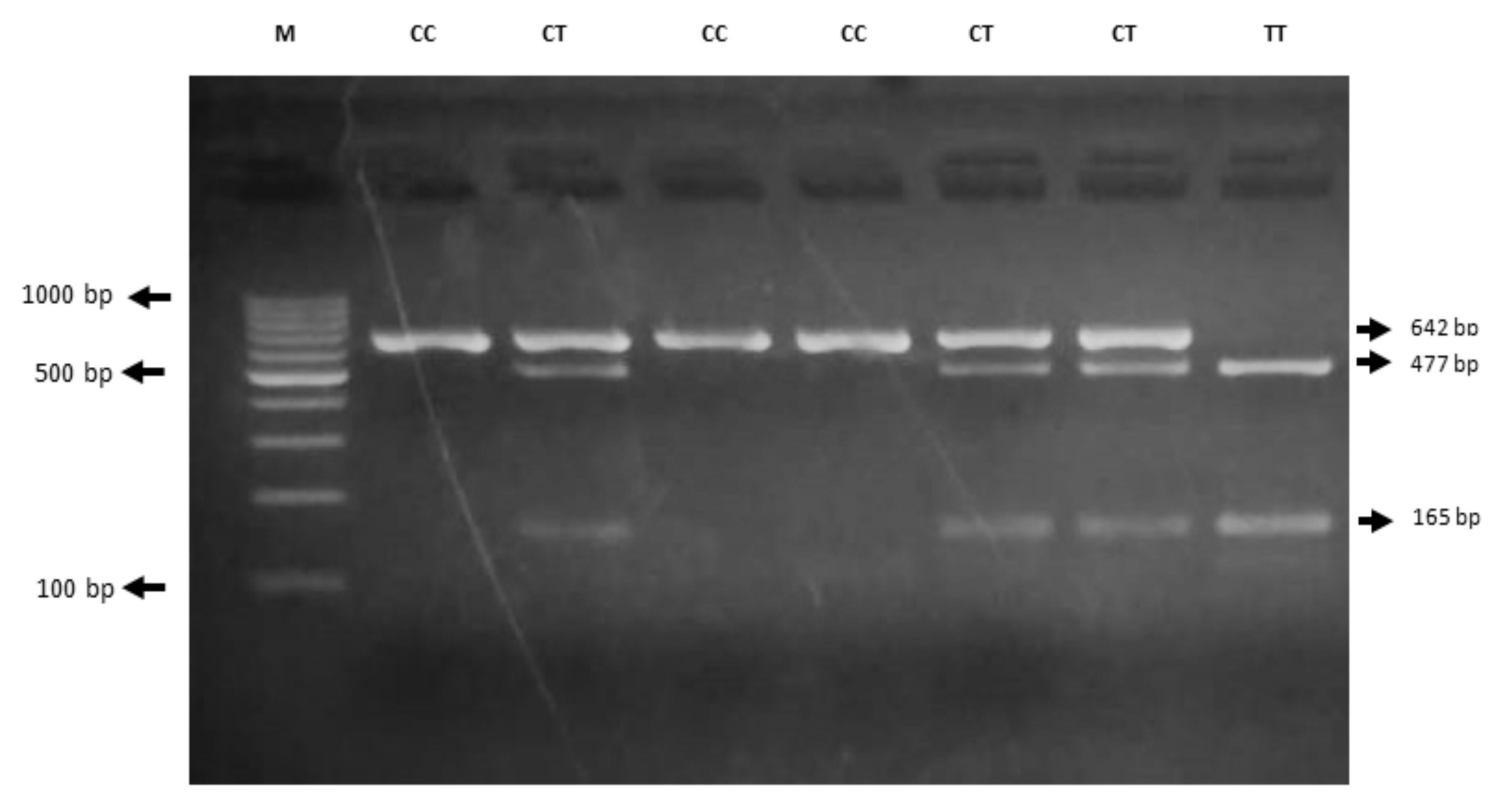

Figure 3. PCR-RFLP Genotyping Results for SNP 1079C $>$ T of MC4R in Bligon Goats. Heterozygote goat with CT genotype was defined when the fragment size being recognized with 165,477 and $642 \mathrm{bp}$, CC genotype with 165 and $477 \mathrm{bp}$ and TT genotype with $642 \mathrm{bp}$; M: marker $1 \mathrm{~Kb}$; 1: PCR product; 2: CT genotype; 3: CC genotype; 4: TT genotype (Agorese 3\%, 50 volt for 1 hour).

on milk yield than the TT and CC genotype; $\mathrm{P}<0,05$ (Deng et al., 2016). The SNP g.93G/A polymorphism changed a CCG codon to CCA suggesting synonymous polymorphism because they encode the same amino acid (proline). The back fat of sheep with GA genotype $(0.54 \pm 0.02)$ was higher than that of GG genotype $(0.48 \pm 0.01)$ based on SNP g.93G/A $(\mathrm{p}<0.05)$ (Zou et al., 2014). The SNP g.1104C/T was identified in the result of alignment MC4R gene sequences of goat, sheep, cattle, and buffalo in the same PCR target of CDS MC4R gene. Therefore, the synonymous polymorphisms were important in expression of growth traits. The recommendation of this study is individual AA and AG genotype (g.998A/G), and individual CC and TT genotype (g.1079C/T) including male and female must be selected to get highest growth traits of Bligon.

\section{CONCLUSION}

In the present study, both of the SNPs were 
Table 2. Association of SNP g.998A/G Genotype with Growth Traits

\begin{tabular}{crrr}
\hline \multirow{2}{*}{ Growth traits $(\mathrm{N}=21)$} & \multicolumn{3}{c}{ Genotype } \\
\cline { 2 - 4 } & AA $(\mathrm{N}=10)$ & AG $(\mathrm{N}=8)$ & GG $(\mathrm{N}=3)$ \\
\hline BW & $3.6 \pm 0.4$ & $3.7 \pm 0.4$ & $3.1 \pm 1.0$ \\
BBL & $32.0 \pm 1.6$ & $31.5 \pm 3.4$ & $30.7 \pm 5.0$ \\
BCC & $33.5 \pm 1.9$ & $34.9 \pm 2.4$ & $33.8 \pm 3.8$ \\
BHS & $35.9 \pm 1.3$ & $38.2 \pm 2.7$ & $33.1 \pm 5.8$ \\
BHH & $37.5 \pm 2.6$ & $39.6 \pm 2.0$ & $37.4 \pm 4.3$ \\
WW & $13.0 \pm 1.7^{\mathrm{a}}$ & $11.2 \pm 3.6^{\mathrm{a}}$ & $9.2 \pm 3.9^{\mathrm{b}}$ \\
WBL & $46.8 \pm 2.4^{\mathrm{a}}$ & $46.3 \pm 6.0^{\mathrm{a}}$ & $43.8 \pm 5.3^{\mathrm{b}}$ \\
WCC & $50.9 \pm 4.0^{\mathrm{a}}$ & $50.7 \pm 4.6^{\mathrm{a}}$ & $47.1 \pm 7.3^{\mathrm{b}}$ \\
WHS & $58.2 \pm 3.2$ & $55.2 \pm 6.2$ & $51.9 \pm 6.5$ \\
WHH & $56.7 \pm 4.5$ & $56.1 \pm 4.0$ & $53.2 \pm 8.3$ \\
ADG & $82.3 \pm 1.0$ & $82.3 \pm 4.9$ & $81.3 \pm 5.3$ \\
\hline
\end{tabular}

$\mathrm{N}$ : number of animal; BW: birth weight (kg); BBL: birth body lenght $(\mathrm{cm})$; BCC: birth chest circumference $(\mathrm{cm})$; BHS: birth height of shoulder $(\mathrm{cm})$; BHH: birth height of hip (cm); WW: weaning weight $(\mathrm{kg})$; WBL: weaning body lenght $(\mathrm{cm})$; WCC: weaning chest circumference $(\mathrm{cm})$; WHS: weaning height of shoulder $(\mathrm{cm})$; WHH: weaning height of hip $(\mathrm{cm})$; ADG: average daily gain $(\mathrm{g})$.

$(\mathrm{a}, \mathrm{b})$ different superscripts at the same raw indicate significant differences $(\mathrm{P}<0.05)$

Table 3. Association of SNP g.1079C/T Genotype with Growth Traits

\begin{tabular}{cccc}
\hline \multirow{2}{*}{ Growth traits $(\mathrm{N}=77)$} & \multicolumn{3}{c}{ Genotype } \\
\cline { 2 - 4 } & CC $(\mathrm{N}=46)$ & $\mathrm{CT}(\mathrm{N}=22)$ & TT $(\mathrm{N}=9)$ \\
\hline BW & $3.3 \pm 0.5$ & $3.4 \pm 0.4$ & $3.3 \pm 0.6$ \\
BBL & $31.1 \pm 3.6$ & $30.1 \pm 4.4$ & $30.2 \pm 3.3$ \\
BCC & $33.2 \pm 2.9$ & $33.7 \pm 3.2$ & $32.8 \pm 2.4$ \\
BHS & $33.9 \pm 2.6$ & $33.9 \pm 3.3$ & $33.0 \pm 3.2$ \\
BHH & $35.4 \pm 3.7$ & $35.4 \pm 3.5$ & $35.4 \pm 3.1$ \\
WW & $12.6 \pm 2.1^{\mathrm{a}}$ & $12.5 \pm 2.5^{\mathrm{a}}$ & $10.6 \pm 3.1^{\mathrm{b}}$ \\
WBL & $48.8 \pm 5.1$ & $49.0 \pm 5.6$ & $47.2 \pm 4.2$ \\
WCC & $51.7 \pm 5.8$ & $53.8 \pm 6.9$ & $51.5 \pm 5.1$ \\
WHS & $58.6 \pm 5.7$ & $57.5 \pm 6.0$ & $56.4 \pm 4.4$ \\
WHH & $56.7 \pm 5.8$ & $59.0 \pm 6.2$ & $57.3 \pm 4.8$ \\
ADG & $81.2 \pm 21.86^{\mathrm{a}}$ & $79.3 \pm 26.2^{\mathrm{a}}$ & $58.3 \pm 30.5^{\mathrm{b}}$ \\
\hline
\end{tabular}

See Table 2. 
consistent in HWE. The SNP g.998A/G was significantly associated with WW, WBL and WCC $(p<0.05)$, and the polymorphism at g.1079C/T has high relationship with $\mathrm{WW}$ and ADG $(p<0.05)$. Our result suggested that MC4R gene might have a potential effect on growth traits in Bligon.

\section{ACKNOWLEDGMENTS}

The study was supported by the grant from Indonesia Higher Education (Dikti) in PMDSU (Master Program of Education Leading to Doctoral Degree for Excellent Graduates) program scheme with contract no. 1987/UN1P.III/LT/DIT-LIT/2017. Thank to Akhmad Fathoni, Hanum Muarifah, Niken Rahmawati, Minuk Kusmia, Dwi Ahmad Priyadi, Amir Husaini, Eris Riswanto, Nur Muhammad and Dwi Nur Happy Hariyono for helping data collection. The authors grateful as well to Retno Setyawati for helping DNA analysis.

\section{REFERENCES}

Anderson, E. J. P., I. Cakir, S. J. Carrington, R. D. Cone, M.G. Langroudi, T. Gillyard, L.E. Gimenez and M. J. Litt. 2016. Regulation of feeding and energy homeostasis by $\alpha-\mathrm{MSH}$. J. Mol. Endoc. 56(3): 157-174.

Budisatria, I.G.S., D. Widayati, B. Suhartanto, Kustantinah, H. Mulyadi dan K.A. Santosa. 2009. Germ Plasm of Goats in Indonesia. CV. Bawah Sadar. Yogyakarta:8

Cai, X., T. D. Mipam, F. F. Zhao, and L. Sun. 2015. SNPs detected in the yak MC4R gene and their association with growth traits. J. Animal. 9: 1097-1103

Davoli R., S. Braglia, V. Valastro, C. Annarratone, M. Comella, P. Zambonelli, I. Nisi, M. Gallo, L. Buttazzoni and V. Russo. 2012. Analysis of MC4R polymorphism in Italian Large White and Italian Duroc pigs: Association with carcass traits. J. Meat Sci. 90: 887-89.

Deng, T. X., C. Y. Pang, M. Q. Liu, C. Zhang, \& X. W. Liang. 2016. Synonymous single nucleotide polymorphisms in the MC4R gene that are significantly associated with milk production traits in water buffaloes. $\mathrm{J}$. Gen. Mol. Res. 15:1-8.

El-Sabrout K. 2017. Associations between singlenucleotide polymorphisms of melanocortin gene and sexual desire behavior in rabbit
(Oryctolagus cuniculus). J. Vet. Beh. 19. 6971.

El-Sabrout K. and F. Soliman. 2017. Association of single- nucleotide polymorphism of melanocortin gene with feed intake in rabbit (Oryctolagus cuniculus). J Anim Physiol Anim Nutr. 00:1-4.

Fontanesi L., E. Scotti, K. Cisarova, P. D. Battista, S. Dall'Olio, D. Fornasini and A. Frabetti. 2013. A missense mutation in the rabbit melanocortin 4 receptor (mc4r) gene is associated with finishing weight in a meat rabbit line. J. Anim. Biotec.. 24(4): 268-277.

Hardjosubroto, W. 1994. Aplikasi Pemuliaan Ternak di Lapangan. Grasindo. Jakarta:210227.

Hartatik, T. 2014. Analisis Genetik Ternak Lokal. Gadjah Mada University Press. Yogyakarta: 75-88.

Hartatik, T. 2016. Pendekatan Praktis Deteksi Polimorfisme DNA Sapi Aceh. Gadjah Mada University Press. Yogyakarta:118134.

Huang, M., X. Gou and J. Y. Li. 2010. Polymorphisms in MC4R gene and correlations with economic traits in cattle. J. Mol. Biol. Rep. 37:3941-3944. https://doi.org/10.1007/s11033-010-0051-0

Jun, Z., Q. Yong, Z. Sheng, C. Hua, W. H. Li, L.Y. Xia, and C. S. Xian. 2013. Single nucleotide polymorphisms of gene fragment of melanocortin receptor-4 C-terminal and its association with body weight in Boer goats. Jiangsu J. Agr. Sci. 6. (Abstract).

Latifah, D. A. Priyadi, D. Maharani, Kustantinah and T. Hartatik. 2017. Genetic Analysis Using Partial Sequencing of Melanocortin 4 Receptor (MC4R) Gene in Bligon Goat. J. Med. Pet.. 40(2):71-77.

Liu, H., W. Tian, L. Zang, H. Wang and H. Cui. 2010. Mutations of MC4R gene and its association with economic traits in Qinchuan catle. J. Mol. Biol. Rep. 37:535540.

Maharani, D., A. Fathoni, Sumadi, T. Hartatik and M. Khusnudin. 2018. Identification of MC4R gene and its association with body weight and body size in Kebumen Ongole Grade cattle. J. Indonesian Trop. Anim. Agric. 43(2):87-93.

Piorkowska, K., M. Tyra, M. Rogoz, K. R. Molik, M. Oczkowicz, and M. Rozycki. 2010. Association of the melanocortin-4 receptor (MC4R) with feed intake, growth, fatness 
and carcass composition in pigs raised in Poland. J. Meat Sci. 85:297-301.

Seong, J., S. S. Dong, D. P. Kyung, K. L. Hak, and S. K. Hong. 2011. Identification and analysis of MC4R polymorphisms and their association with economic traits of Korean cattle (Hanwoo). J. Mol. Biol. Rep. 39: 3597-3601.

Song, X. M., J. F. Jiang, G. Z. Zhang, F. X. Shiand, and Y. Q. Jiang. 2012. DNA polymorphisms of the $\mathrm{Hu}$ sheep melanocortin-4 receptor gene associated with birth weight and 45-day weaning weight. J. Gen. Mol. Res. 11:4432-4441.

Suhartanto, B dan Kustantinah. 2009. Goat Feeding. In: Budisatria, I.G.S., D. Widayati, B. Suhartanto, Kustantinah, H. Mulyadi dan K.A. Santosa. Germ Plasm of Goats in Indonesia. CV. Bawah Sadar. Yogyakarta: 45.

Wang, Y., C. Wang, J. Zhang, C. Meng, X. Zhang, Z. Wang, Y. Fang, D. Mao and S. Cao. 2015. Three novel MC4R SNPs associated with growth traits in $\mathrm{Hu}$ sheep and East Friesian $x \mathrm{Hu}$ crossbreed sheep. Small Rum. Res. 125:26-33.

Yan, L. J., X. T. Fang, Y. Liu, C. L. Zhang, X X Liu, J. Zhao, J. J. Li and H. Chen. 2013. Effects of single and combined genotypes of MC4R and POU1F1 genes on two production traits in Langshan chicken. J. Mol. Biol. Rep. 40:4645-4650.

Zhang, J., J. Chai, Z. Luo, H. He, L. Chen, X. Liu and Q. Zhou. 2017. Meat and nutritional quality comparison of purebred and crossbred pigs. Anim. Sci. Jour. 89(1):202210.

Zheng, R., Y. Zhang and P. Du. 2014. The SNPs of Melanocortin 4 Receptor (MC4R) associated with Body Weight in Beagle Dogs. J. Exp. Anim. 63(1):73-78.

Zuo, B., G. Liu, Y. Peng, H. Qian, J. Liu, X. Jiang, and A. Mara. 2014. Melanocortin-4 receptor $(M C 4 R)$ polymorphisms are associated with growth and meat quality traits in sheep. J. Mol. Biol. Rep. 41:6967-6974. 